\title{
EFFECT OF ADRENALINE ON NITROGLYCOL POISONED MICE
}

Sudden occurrence of angina pectoris like attack or sometimes even fatal outcome on the day following holiday in the workers of dynamite plants is still an important problem.

Although there are ample circumstantial evidences which indicate that the chronic exposure of workers to nitroglycol is a cause of the episodes, no diagnostic measures for the chronic poisoning have been available and animal experiments have also failed to reproduce a type of intoxication similar to human's.

It has been postulated that nitroglycol's vaso acting properties which might be mediated by an alteration of catecholamine metabolism have something to do with the occurrence of the attack. In line with this hypothesis we found that administration of copper, which was though to decompose catecholamine, was effective to extend the survival period in nitroglycol poisoned mice ${ }^{\prime \prime}$ and the total copper level and ceruloplasmine activity in plasma increased gradually with acute nitroglycol poisoning in rabbit ${ }^{2)}$. And recently, Hotta and Yamad ${ }^{3)}$ reported decreased urinary excretion of noradrenaline in nitroglycol exposed workers.

In this connection, the effect of adrenaline administration to nitroglycol poisoned mice was studied. Twenty male mice (CF-1 Strain) were injected with nitroglycol $(100 \mathrm{mg} / \mathrm{kg})$ in olive oil subcutaneously for successive 14 days. To another ten male mice cupric sulfate (copper of $1 \mathrm{mg} / \mathrm{kg}$ ) was injected subcutaneously 1 hour prior to nitroglycol $(100 \mathrm{mg} / \mathrm{kg})$ for the same period. All mice in these experimental groups survived at least for 14 days, and weight gain was same as controls. No symptoms could be recognized.

After 14 days administration, ten out of twenty mice treated with nitroglycol alone received subcutaneous injection of adrenaline $(2 \mathrm{mg} / \mathrm{kg})$ daily for the succeeding 4 days (Group A). Same doses of adrenaline was injected for 4 days to remaining ten nitroglycol treated mice which had been kept free from nitroglycol for 2 days after 14 days treatment (Group B). Finally to nitroglycol and copper treated ten mice the same doses of adrenaline was administered in the same manner as Group B (Group C). The survival rates obtained from these three groups of adrenaline injection are illustrated in Fig. 1.

As shown in Fig. 1, in the Group A, one mouse died at the first day and 6 mice survived after 4 days. In the Group B, 4 mice died at the first day and one mouse survived after 4 days. These results suggest that the sensitivity to large dose adrenaline in the nitroglycol poisoned mice increased remarkably after two day recess of nitroglycol. In the Group C, 2 mice died at the first day and 5 mice 


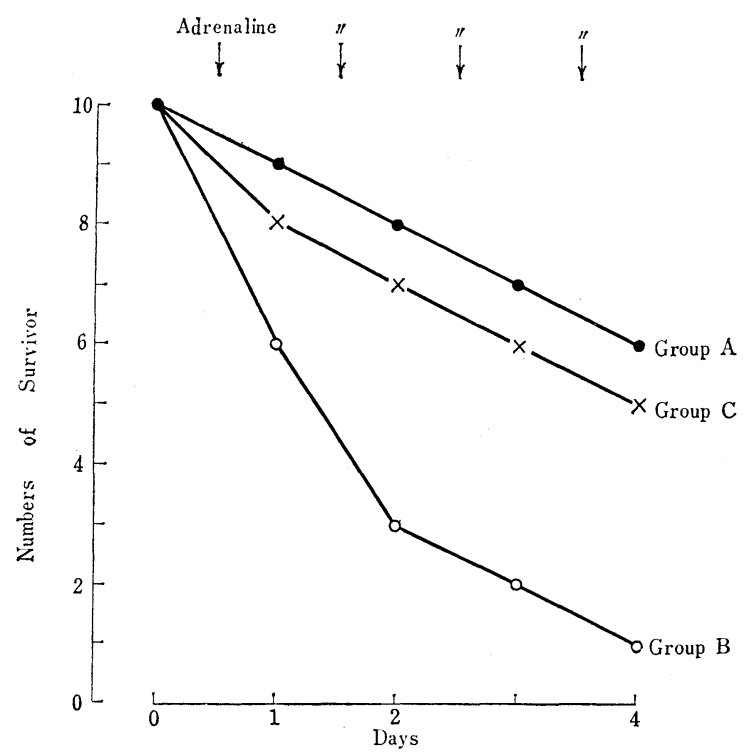

- $100 \mathrm{mg} / \mathrm{kg}$ Nitroglycol, S.C., daily for 14 days, $\stackrel{\text { from next day }}{\longrightarrow}$ adrenaline $2 \mathrm{mg} / \mathrm{kg}$, S.C., daily for 4 days.

after 2 days freedom

$\bigcirc \longrightarrow 0100 \mathrm{mg} / \mathrm{kg}$ Nitroglycol, S.C., daily for 14 days, $\stackrel{\text { after } 2 \text { days freedom }}{\longrightarrow}$ adrenaline $2 \mathrm{mg} / \mathrm{kg}$, S.C., daily for 4 days.

after 2 days freedom

$\times \longrightarrow \times 100 \mathrm{mg} / \mathrm{kg}$ Nitroglycol, and $1 \mathrm{mg} / \mathrm{kg}$ copper, S.C., daily for 14 days adrenaline $2 \mathrm{mg} / \mathrm{kg}$, S.C., daily for 4 days.

Fig. 1. Comparison of survival period caused by adrenaline on nitroglycol poisoned mice in three groups.

survived after 4 days. These data show that no significant difference of mortality was recognized between the Group A and Group C, suggesting that administration of copper might suppress to some extent the sensitivity of the nitroglycol poisoned mice to administered adrenaline.

These results indicate that abrupt cessation following long term administration of nitroglycol may cause a derangement in the catecholamine metabolism.

\section{REFERENCES}

1) Yoshikawa, H. and Ishii, M. (1962). Bull. Nat. Inst. Ind. Health, 7, 1.

2) Yoshikawa, H. to be printed.

3) Hotta, K. and Yamada, R. (1963). Intern. Arch. Gewerbepathol. Gewerbehyg., 20, 311.

National Institute of Industrial Health

Hiroshi YOSHIKAWA

Kizuki-Sumiyoshi

Kawasaki

Received May 6, 1964 